\begin{tabular}{|c|c|}
\hline & \\
\hline 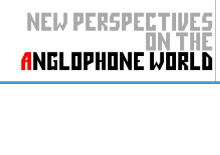 & $\begin{array}{l}\text { New Perspectives on the Anglophone World } \\
\mathbf{8} \mid \mathbf{2 0 1 9} \\
\text { Neoliberalism in the Anqlophone World }\end{array}$ \\
\hline
\end{tabular}

\title{
Video introduction to issue 8
}

\section{Simon Dawes and Marc Lenormand}

\section{(2) OpenEdition}

\section{Journals}

Electronic version

URL: https://journals.openedition.org/angles/555

DOI: 10.4000/angles.555

ISSN: 2274-2042

\section{Publisher}

Société des Anglicistes de l'Enseignement Supérieur

\section{Electronic reference}

Simon Dawes and Marc Lenormand, "Video introduction to issue 8", Angles [Online], 8| 2019, Online since 01 April 2019, connection on 07 June 2022. URL: http://journals.openedition.org/angles/555 ; DOI: https://doi.org/10.4000/angles.555

This text was automatically generated on 7 June 2022.

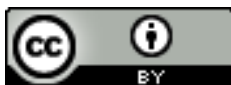

Angles est mise à disposition selon les termes de la Licence Creative Commons Attribution 4.0 International. 


\title{
Video introduction to issue 8
}

\author{
Simon Dawes and Marc Lenormand
}

This media file cannot be displayed. Please refer to the online document http:// journals.openedition.org/angles/555

\section{Transcript:}

1 I'm Marc Lenormand, senior lecturer in British Studies at Université Paul-Valéry Montpellier 3. I'm primarily a scholar of trade in history and industrial relations. In my research, I've looked at the evolution of trade unions and their responses to neoliberal policies and austerity policies from the 1970s.

2 I'm Simon Dawes, lecturer in British Studies and cultural industries at the university of Versailles Saint-Quentin. I'm particularly interested in the neoliberalization of media policy in the UK, as well as theories of neoliberalism and liberal theories of press freedom.

3 Particularly outside of academia at the moment since the financial crash, the word 'neoliberalism' has been used more and more, by more and more people without necessarily understanding what the term means or agreeing on what the term means. I's something that people are talking about quite a lot. Inside academia, there are some disciplines in which they have had a methodological debate about what neoliberalism is, whether it exists or not, how best to analyse it... and other disciplines that have been lacking behind somewhat. I think it was important for us to look at the fact that the word 'neoliberalism' is used a lot when we talk about different aspects of the Anglophone world to assess the extent to which it is, or isn't, a useful word to use, and to highlight the different perspectives that are drawn on different academic perspectives, different disciplines, different theoretical and methodological approaches, not necessarily to argue that one is better than others, but just to present the diversity of different approaches to studying various aspects of the neoliberal Anglophone world.

4 There's also this sense that the use of the term has become so inflated that no one knows what it means anymore. There are now some academic journals, for example, that refuse to accept any article that uses the word 'neoliberalism' without making it 
explicit which theoretical position you are adopting, which theorists of neoliberalism you're using. So it's important for us to question whether the word is useful. If we do use it, we can't just use it and assume that everyone understands what we mean. We have to actually engage with the literature on the subject.

These debates in the field of literature specializing in neoliberalism are generally structured around Marxist or Marx-inspired approaches versus, or combined with, Foucault and Foucauldian approaches. They are broadly two different camps. There are those who argue that neoliberalism is an ideology, that we can talk about neoliberal hegemony, and these people tend to adopt a broadly Marxist approach, often using Gramsci. They would cite David Harvey and/or Stuart Hall on neoliberalism. And then we have the different camp which would be Foucauldian or post-Foucauldian, who would cite Foucault's lectures from 1979, his book on the birth of biopolitics. There's also lots of literature that has been written by others since then, using Foucault's ideas, who talk more about neoliberalism as a form of governmentality rather than ideology. And then there are also those who draw on both approaches to argue that we can make bridges between these approaches. And there are those who argue that you cannot, that they are two fundamentally different approaches.

What's important for us with this issue was just showing the diversity. As long as the authors were engaging with the literatures and situating their own perspective within these debates, that was the main thing.

This special issue of Angles is a follow-up to a conference that we organized in Montpellier in 2017 on neoliberalism in the Anglophone world. It was very important for us to show this diversity of topics and approaches, by getting contributions from all the various sub-disciplines of English Studies in France. We have British and American civilization essays, essays on American literature, essays from linguists, as well as from people from all sorts of different disciplines from the Anglophone world.

We've got analysis of public policy in certain specific areas, and we've got discussions of economic policy, employment policy, and also the effects of neoliberal economic policies on a society and on bodies. And you've also got articles dealing more with representations: representing neoliberalism and the crisis, either in terms of visual studies analysis, or more in terms of linguistic analysis, or at least the analysis of rhetoric in discourse. The issue ends with a paper on resistance.

9 This conference happened just after the Brexit vote in the UK and the election of Trump in the US, so those issues were on the minds of everyone at the conference and it's issues like this, events like this, which many people would argue are consequences of neoliberalism, of austerity policies that have been pursued around the world after the financial crash.

As you'll see, in all of the articles in the issue, these issues are mentioned at least briefly. We're filming this video introduction in the middle of the yellow vest protests in France, protests against the French iteration of the neoliberal agenda. And there's also relevance to our immediate context in academia. Academia has been one of the testing grounds for neoliberal policies in the UK and France, among others.

If you look around you, and consider the increasing workload, top-down management, project funding, all the talk of excellence... well, think 'neoliberalism'.

We hope you enjoy the issue! 


\section{ABSTRACTS}

This video introduces the thematic contributions on 'Neoliberalism in the Anglophone world'.

La vidéo présente les contributions thématiques sur « Le néolibéralisme dans le monde ».

\section{INDEX}

Keywords: neoliberalism, United States, United Kingdom, South Africa, economics, politics, governmentality

Mots-clés: néolibéralisme, États-Unis, Royaume-Uni, Afrique du Sud, économie, politique, gouvernementalité

\section{AUTHORS}

\section{SIMON DAWES}

Guest editor of Issue 8. Senior Lecturer at Université de Versailles Saint-Quentin-en-Yvelines and member of the research team, Centre d'histoire culturelle des sociétés contemporaines. He is the founding editor of the open access journal, Media Theory, and the author of British Broadcasting and the Public-Private Dichotomy: Neoliberalism, Citizenship and the Public Sphere (2017, Palgrave Macmillan). His research revolves around issues of media theory, history and regulation, particularly the history and regulation of British and French media. Contact: simondawes0[at]gmail.com

\section{MARC LENORMAND}

Guest editor of Issue 8. Senior Lecturer at the Université Paul Valéry Montpellier 3. His research focuses on the industrial, political and intellectual history of the UK trade union movement and of the broader UK left in the second half of the 20th century. He has written on industrial action in the 1970s, the evolution of trade unions, their relationship with the Labour Party, women in trade unions and left organisations, and the recent history of collective movements. A former member of the Editorial Board and editor of Tracés, he has edited journal issues on education, minorities, political violence and animal rights. Contact: Marc.Lenormand[at]univ-montp3.fr. 